\section{Fahmina Binte Ibrahim ${ }^{1}$ Md. Marufur Rahman ${ }^{1^{*}}$ Nahid Rezwana ${ }^{2}$}

Manuscript Received: 15 November 2019 Accepted: 28 November 2019

'Department of Disaster Science and Management, University of Dhaka, Dhaka 1000, Bangladesh

2Department of Geography and Environment, University of Dhaka, Dhaka 1000, Bangladesh

${ }^{*}$ Corresponding author

Email: maruf.dsm@du.ac.bd

\title{
Non-response to Early Warning: A Comparative Study of Three Recent Cyclones in Bangladesh
}

\begin{abstract}
This study aims to explore the different reasons that influence people's decision on responses to early warning. A questionnaire survey, key informant interviews and focus group discussion have been applied to obtain data from the study area for this study. The research reveals that jerry-built roads, fear of theft, disbelief and mistrust about warnings, lack of awareness about hazards and the poor state of the cyclone shelters are the main reason for nonevacuation during cyclones. Besides, past experiences of warning failures, superstitious religious beliefs, fatalism, safety issues for women also worked to influence people's decision to leave their houses during the warning periods. This study calls the attention of the disaster planners at these crucial findings for taking an immediate step
\end{abstract}

to improve the conditions and save lives in future cyclones. It is highly dangerous to stay at the vulnerable houses during cyclones. The practical implementation of a good disaster preparation plan can be futile if inhabitants are no-responsive to the warning. This study recommends improvement of infrastructures, proper maintenance and construction of shelters, improved security at evacuated houses and the shelters alongside the awareness programs for the inhabitants of the vulnerable locations. It is expected that these interventions will increase the efficiency of the cyclone preparedness plan for future cyclones in Bangladesh.

Keywords: Non-response, Evacuation, Early warnings, Tropical cyclone, Bay of Bengal

\section{Introduction}

The tropical storm cyclone (in some region it is called hurricane or typhoon) is a major threat for the inhabitants living in the coastal zone around the world. Due to these tropical storms, over two million death and about a million injuries have been recorded over the last two century (Haque et al., 2012). The Bay of Bengal is considered as the ideal place for tropical cyclones formation. According to global cyclone statistics, only $7 \%$ of tropical cyclones form in the north Indian Ocean, in case of the Bay of Bengal the number of cyclone formation is higher than the Arabian Sea of north Indian Ocean region (Akter, 2015). The triangular shape of the Bay of Bengal; tropical monsoon climate, high population density in the coastal area makes Bangladesh more vulnerable to cyclones.

However, it is a matter of hope that Bangladesh has made remarkable progress in the field of disaster management by modernizing early warning systems, developing shelters and evacuation plans, constructing coastal embankments, maintaining and improving coastal forest cover, and by raising awareness at the community level (Paul and Routray, 2013; Haque et al., 2012). About 0.7 million deaths recorded in Bangladesh over the last fifty years due to cyclone; however, the number of causalities decreased many folds by recent years (Haque et al., 2012). Cyclone preparedness program (CPP) was launched in 1972 by the Bangladesh Red Crescent Society. From 1973, the CPP program is supported by the government of Bangladesh. The main objective of the CPP program is to lessen the damage of the property and loss of life by developing and building preparedness as well as enhancing the response capacity of the inhabitants of coastal people during cyclones. Improvement in the early warning system, other measures like building cyclone shelter and embankments resulted in reduced number of death during cyclone (Haque et al., 2012). Earlier studies have confirmed that improvement in the early warning and timely dissemination is the root cause for the lowerthan-expected death toll and damage at the time of cyclone Sidr in Bangladesh (Paul and Routray, 2013).

Regardless of having progress in managing the disaster, Bangladesh still experiences a considerable amount of causalities due to cyclone. Mitigation and preparedness measures were failed in the past as people's perception and behavior on warning are not considered or ignored (Alam and Collins, 2010; Charnkol and Tanaboriboon, 2006). A recent study reveals that about $84.7 \%$ of people did not take timely 
refuge after receiving warnings in cyclone Roanu (Rezwana, 2018; Paul, 2014).

Previous research reveals that poor road network and long-distance of shelters, fear of stealing, disbelief of cyclone warning, fatalism, low capacity and unfavorable conditions of cyclone shelter, river barrier, confidence on the strength of own house, age barrier, poor understanding of warning are the reasons for reluctant evacuation or non-evacuation to shelter during a cyclones. (Haque and Blair, 1992; Chowdhury et al., 1993; Islam et al., 2004; Paul and Rahman, 2006; Paul, 2008 and 2010; Paul and Dutt, 2010; Alam, and Collins., 2010; Paul and Routray, 2013; Rezwana, 2018).

The purpose of this study is to analyze the causes of non-response during the warning periods and get a comparative picture of three recent cyclones in Bangladesh; cyclone Mahasen in 2013, cyclone Roanu in 2016 and cyclone Mora in 2017. This comparative analysis will help to understand the warning response situations during these three cyclones and help to take preparedness measures for the future cyclones.

\section{Literature Review}

Understanding people's response behavior to early warning for evacuation is crucial for reducing human causalities in any disaster. However, only a few numbers of researches have been conducted on this topic. Whitehead et al. (2000) in their research on evaluating hurricane evacuation behavior reveals that likelihood to move to shelter is lower among the nonwhite people, people having pets and among more educated people in the time of hurricane Bonnie in North Carolina, USA. The study of Smith and M cCarty (2009) exhibits that disbelief and misconception about the hurricane, concern about the pet and unattended household member, lack of transportation, medical condition, job responsibilities and lack of time for evacuation as the reasons for unwillingness to move to shelter in Florida. Lack of shelter and transportation, financial condition, concern about property and job, health problems, an obligation to the elderly members, ambiguous evacuation message, previous experience of no damage, and distrust in authority impeded the evacuation of peoples of New Orleans in the USA at the time of hurricane Katrina (Eisenman et al., 2007). However, in the study of Elder et al. (2007), found that racism and inequities, religious faith, neighborhood crime as the reasons that affect the evacuation decision of African American people residing in New Orleans. Lazo et al. (2010) mention that less-educated people and people from the high-income group are less likely to evacuate to shelter. People who are more educated, young and have a high income are less likely to move to shelter according to the study of Reininger et al. (2013).

In previous studies, the researcher found that the reasons for refusing to evacuate to shelter during a cyclone in Bangladesh are fear of burglary and theft, disbelief on warning, lack of shelter in the vicinity, poor condition of shelter, poor road network, religious belief, dependency on fate, illiteracy, conservative and superstitious characteristics, confusion and dilemma, the significant distance between home and cyclone shelter, misinterpretation of warning, disbelief in cyclone warning, inappropriate warning, cultural issues, the experience of the failure of early warning and false warning (Haque and Blair, 1992; Chowdhury et al., 1993; Islam et al., 2004; Paul and Rahman, 2006; Paul, 2008 and 2010; Paul and Dutt 2010; Alam, and Collins, 2010; Paul and Routray, 2013; Rezwana, 2018).

However, people of Bangladesh experiences significant damages and human causalities in the previous cyclone like the cyclones in 1970, 1985, 1991 and 1997 due to lack of cyclone preparedness and awareness (Paul and Rahman, 2006; Chowdhury et al., 1993). So far, Bangladesh achieved significant progress in cyclone preparedness by improving cyclone warning, building shelters and raising awareness among people which results in a lower number of human casualties in cyclone Sidr, 2007 (Paul and Dutt, 2010). Despite, these advancements people are still reluctant to go to shelter and response to cyclone warning.

By reviewing existing literature, it can be said that very few researches have been conducted on human behavior for ignoring the early warning in Bangladesh. This paper aims to find the causes of non-response to cyclone warning in case of three recent cyclones in Bangladesh.

\section{Methodology}

Both primary and secondary data have been used to complete this study. Secondary data have been collected from different published and unpublished sources, including the Bangladesh bureau of statistics (BBS). For the collection of primary data, a field survey has been conducted in the study area in 2018. Data collection methods include questionnaire survey, 
focus group discussion (FGDs), key informant interviews (KII) and observation. For the questionnaire survey, the sample size has been calculated by considering a $90 \%$ confidence level and $5 \%$ margin of errors. Total 253 households were surveyed among 4193 in the study area, Kalapania Union and Harishpur Union of Sandwip Upazila. We conducted key informant interviews (ten) among local political leaders, teachers, doctors, village polices and with cyclone preparedness program (CPP) members. Eight FGDs with local residence (five), political leaders (two in two unions), and CPP members (one) have been conducted.

\section{Study Area}

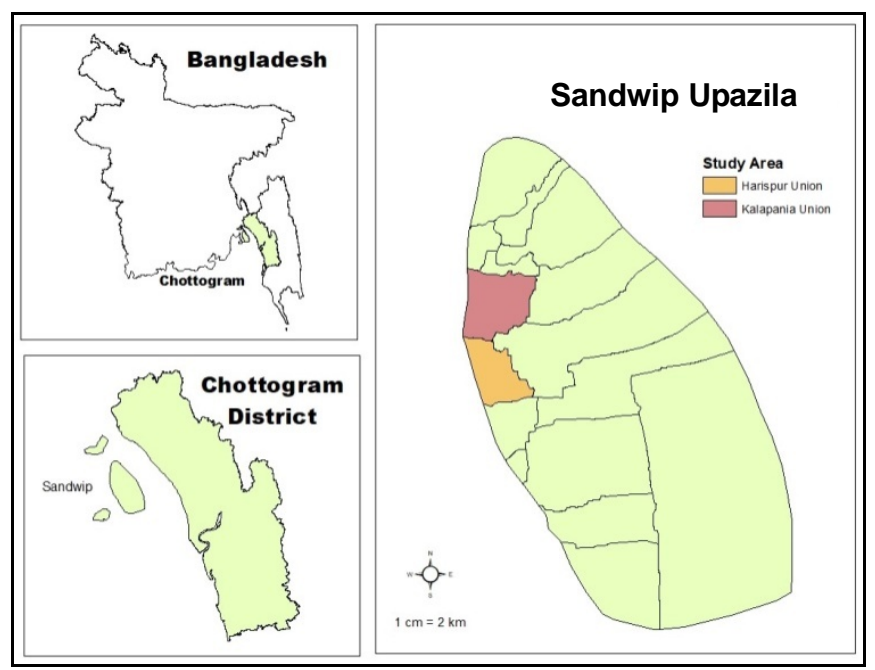

Figure 1: Map of the Study Area

Sandwip upazila of Chattogram district have been selected for this study (Figure 1). All three cyclones (Mahasen in 2013, Roanu 2016 and Mora in 2017) formed in May and hit Sandwip upazila during landfalls. Sandwip Upazila is an offshore island and extremely prone to the cyclone. Due to its location, previous cyclones caused severe damage to this area. The position of Sandwip is at the estuary of the Meghna River on the Bay of Bengal. It is located between $22^{\circ} 16^{\prime}$ and $22^{\circ} 43^{\prime}$ north latitudes and in between $91^{\circ} 17^{\prime}$ and $91^{\circ} 37^{\prime}$ east longitudes (Banglapedia, 2014). It is located at the frequent pathway of tropical cyclone (Uddin and Ciavola, 2012). Substantial damages to the settlement, crop fields, livestock and properties in Sandwip had caused due to devastating cyclone of 1877, 1963, 1970, 1985 1991, 1997 (Banglapedia, 2014). The study from Paul and Rahman, (2006) shows that people from Sandwip is less aware of the risk of hazards than the people of nearby islands like Hatiya. The shelter management and relief management system is also less developed in Sandwip than Hatiya. The total area of the island is vulnerable to the cyclone hazard. The total area is $762.42 \mathrm{sq} . \mathrm{Km}$ and the total population of the island are 278,605 (BBS, 2013). Among 15 unions of the upazila two unions, Kalapania and Harishpur have been selected for this study.

\section{Results and Discussion}

In this study, $87.3 \%$ of respondents are male, and $12.7 \%$ of respondents are female. Most of the respondents are adults (age 19 years or above). They are involved in farming (22.1\%), fishing (10\%), service $(6.8 \%)$, business (15\%) and other occupation (42\%) like the driver, mason, daily labor, carpenter, imam a cobbler. The remaining $4.1 \%$ of the respondents are dependent. M ost of the households (86.5\%) consist of 3 to 7 family members.

\section{Vulnerability Context}

Sandwip is extremely vulnerable for cyclone disasters due to its location. As stated by the people while conducting FGDs, most of the houses inundate during high tides at Kalapania and Harishpur Unions. Most of the houses are made of tin and wood (88.18\%) or shon grass (a kind of grass used for thatching roof) $(2.82 \%)$ and only $9.09 \%$ have pucca or semi pucca house (made of brick and cement). This weak housing pattern exacerbates the vulnerability of the people who reside in this region. Even a slightly strong storm can destroy their houses. Most of the roads are kutcha or damaged. Cement concrete roads are mostly damaged due to inundation of water during high tides and by rain water. As a result, their transportation facilities are very weak, and communication becomes very cumbersome during disasters. The residents informed that transportation cost is high in the study area, which becomes a strong influencing factor in the course of moving to a safer place during a cyclone. The socio-economic condition of the respondents in the study was quite low. About $45 \%$ of respondents earn less than 10,000 taka per month, about $38.6 \%$ of them earn 10,000-20,000 taka per month and 16.4\% of the respondents earn more than 20,000 taka per month (field survey 2018). The low socio-economic condition can hinder the opportunities and privileges granted to peoples' life and consequently decrease the ability to withstand hazards. 


\section{Reception and Dissemination Media of Cyclone Early Warning}

In Sandwip, most of the respondent (93.18\%) received a warning during cyclone Mahasen. About $6.82 \%$ did not receive any warning as they were in a remote place where megaphone or other sources could not reach. However, during cyclone Roanu and cyclone Mora all of the respondents received early warnings (Figure 2 ).

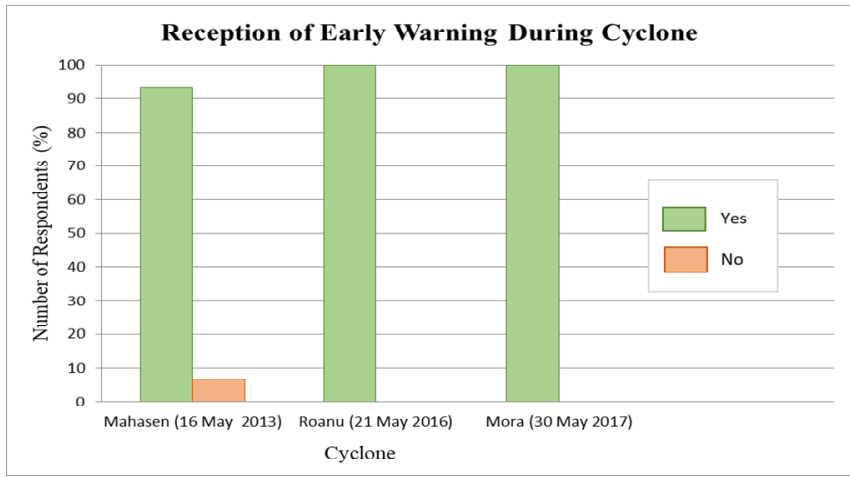

Figure 2: Number of Respondents Received Early Warning during Cyclone

Source: Field study, 2018

It has been revealed from the study that the highest number of inhabitants received warnings through megaphones (around $80 \%$ ), then radio, mobile phones and other sources (neighbors and friends). However, many respondents received warnings from multiple sources rather than only one source. Newspaper and electronic media were not popular among the inhabitants of the study area for receiving cyclone warning (Figure 3).

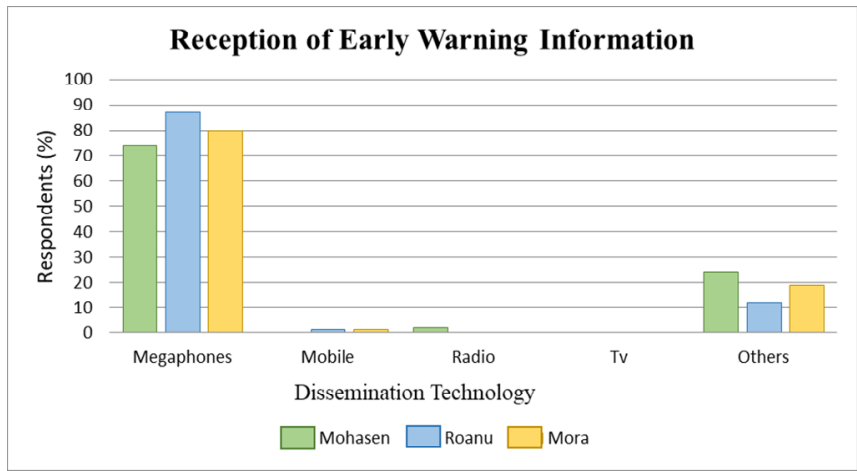

Figure 3: Reception of Early Warning Information M ediums. Source: Field study, 2018

\section{Response to Cyclone Warning}

Evacuation to shelter or safer place after receiving the warning is a part of preparedness and also conducive for reducing substantial loss and damages caused by disasters. However, people are reluctant to go to safe shelters even after receiving warnings. This study shows that $41.82 \%$ of respondents during cyclone Mahasen, 45\% respondents during cyclone Roanu and $50.54 \%$ respondents during cyclone Mora did not evacuate their vulnerable houses for shelters (Figure 4). However, the respondents who evacuated for the safe shelter went to a nearby school, college, hospitals, mosque and relative's house (Table 1).

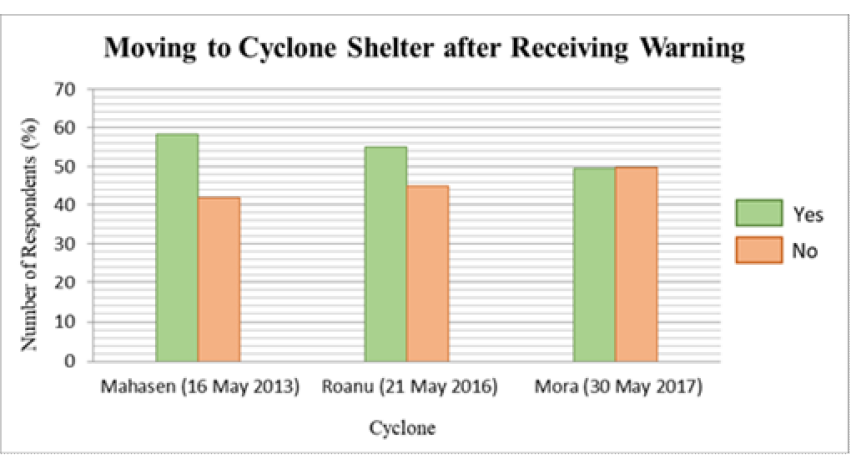

Figure 4: Taking Shelter after Receiving Warning Information

Source: Field study, 2018

Table 1: Type of Cyclone Shelters Preferred by Respondents

\begin{tabular}{|c|c|c|c|c|c|}
\hline Cyclone & $\begin{array}{l}\frac{8}{8} \\
\frac{8}{8} \\
\frac{8}{4}\end{array}$ & $\begin{array}{l}\frac{8}{8} \\
\frac{8}{8} \\
\overline{\bar{\theta}}\end{array}$ & 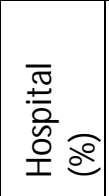 & 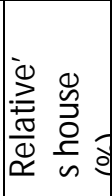 & $\begin{array}{l}0 \\
\overline{0} \\
0 \\
\Sigma\end{array}$ \\
\hline Mahasen (May 16, 2013) & 76 & 9.6 & 11.1 & 3.30 & - \\
\hline Roanu (M ay 21, 2016) & 72.13 & 10.75 & 10.75 & 6.37 & - \\
\hline Mora (30 M ay 2017) & 76.69 & 8.06 & 3.92 & 10.24 & 1.09 \\
\hline
\end{tabular}

Source: Field study, 2018

However, the respondents who evacuated for the shelter left their home when the heavy wind started to increase. Few of them only went to shelter just a few hours before the wind speed started to increase. During cyclone Mahasen, Roanu and Mora, respectively $66.42 \%, 62.02 \%$ and $70.74 \%$ of respondents took refuge to shelter when the heavy wind started (field survey 2018).

\section{Reasons for Not Evacuating to Shelter}

The previous discussion of this study has disclosed that although a significant number of people took refuge to shelter, yet there are a considerable number of people who did not leave their houses during the warning period. The reasons behind not going to shelters were: fear of theft, poor condition of cyclone shelter, lack of cyclone shelters in the vicinity, presence of an old member in the family, safety issue for female members, 
not receiving warnings, previous bitter experience and lack of knowledge regarding cyclone (Table 2).

Table 2: Reasons for Not Going to Shelter after Receiving Warning Information.

\begin{tabular}{|l|c|c|c|}
\hline $\begin{array}{l}\text { Reasons for not going to } \\
\text { shelter }\end{array}$ & $\begin{array}{c}\text { Mahasen } \\
(\%)\end{array}$ & $\begin{array}{c}\text { Roanu } \\
(\%)\end{array}$ & $\begin{array}{c}\text { M ora } \\
(\%)\end{array}$ \\
\hline $\begin{array}{l}\text { Fear of theft at the } \\
\text { evacuated house }\end{array}$ & 6.8 & 8.6 & 8.2 \\
\hline $\begin{array}{l}\text { Poor condition of cyclone } \\
\text { shelter }\end{array}$ & 1.8 & 5 & 10.5 \\
\hline Lack of cyclone shelter & 2.4 & 1.9 & 2.7 \\
\hline $\begin{array}{l}\text { Presence of old member in } \\
\text { family }\end{array}$ & 0.9 & 1.8 & 0.5 \\
\hline $\begin{array}{l}\text { Fear of abuse of the female } \\
\text { member at the shelter }\end{array}$ & 3.6 & 5.5 & 2.4 \\
\hline Didn't receive warnings & 4.5 & - & - \\
\hline Previous experience & 27.18 & 23.79 & 40.01 \\
\hline $\begin{array}{l}\text { Cyclone shelter close to } \\
\text { house }\end{array}$ & 1.9 & 1.3 & 0.5 \\
\hline $\begin{array}{l}\text { Concrete building of } \\
\text { neighbor }\end{array}$ & 2.3 & 2.3 & 2.3 \\
\hline $\begin{array}{l}\text { Family members separated } \\
\text { in shelter }\end{array}$ & 0.5 & - & - \\
\hline $\begin{array}{l}\text { Believe that their house is } \\
\text { strong }\end{array}$ & 23.81 & 25.15 & 19.43 \\
\hline Not answered & 24.32 & 24.66 & 13.46 \\
\hline
\end{tabular}

Source: Field study, 2018

According to the field survey, $27.18 \%$ of respondents during cyclone Mahasen, $23.79 \%$ of respondents during cyclone Roanu and $40.01 \%$ of respondents during cyclone Mora refused to go to the shelter due to their previous experience. Since few cyclones in the past did not hit the study area despite dissemination of early warning, they lost belief on early warnings.

Respondents did not leave their house as cyclone shelter was very close to their house or their neighbors' concrete or pucca building was nearby. They were determined to leave the house when the cyclone would strike. They thought they could quickly move and reach to the shelters. However, they are not aware that it could take their lives. Again, $23.81 \%$ of respondents during cyclone Mahasen, $25.15 \%$ of respondents during cyclone Roanu and $19.43 \%$ respondents during cyclone Mora refused to go to the shelter as they were confident about their house conditions. They believe their houses are strong enough to keep them safe in cyclones.

The survey exhibits that few respondents claim a lack of shelter in their vicinity. There were many buildings which were used as a cyclone shelter, but most of these were in a dilapidated condition, and the respondents were not counting them as a safe shelter. In Kalapania Union, a hospital is considered as a cyclone shelter which is damaged, hence abandoned in the normal time.

Furthermore, there is no cyclone shelter or concrete building close to this hospital. Moreover, people who live near the dam are more vulnerable to cyclone due to their location of settlements and socio-economic conditions. During the cyclone Mahasen, Roanu and Mora, respectively $1.8 \%, 5 \%$ and 10.5 of respondents claim that unsafe shelters as the reason for not going (Table 2). A respondent in Harishpur Union informed that the concrete wall of the school building which was supposed to be used as a cyclone shelter is falling apart. As a result, they are afraid to believe that those shelters will help to protect their lives during cyclone.

Evacuation rate is lower in a high-income household that the low and middle-income household. Only $36.11 \%$ of respondents with high income have evacuated during cyclone Mora and remaining $63.89 \%$ stayed in their houses. However, $61.25 \%$ of respondents with income between 10000-15000 takas went to safe shelter, and $38.75 \%$ of them did not take any shelter during cyclone Mora. Respondents with low to medium income acted positively to warnings than the respondents with high income. The reason can be high-income people have the ability to build more durable houses than people with low to medium income. Moreover, they have more assets which they may want to protect from damage. While the ability to withstand disaster is low, those are having a low income. It revealed from interviews that despite having a desire to go to shelters; rich people stay at home as they do not seem interested to stay together with a poor one. A few of them think that it is not respectful for them to take refuge in a cyclone shelter.

The survey results also reveal that people with resources (e.g. cattle, fish cultivation and land) are more reluctant to evacuate to shelter. The exact number could not be ascertained because people are not comfortable for sharing this information. Out of all the respondents, few claimed that they did not feel safe to go to the shelter for the presence of senior/aged member and female members of the family. Notably, families with adolescent girls did not 
wish to go to the shelter. In the study area $60 \%$ household has an adolescent family member and of which $40.91 \%$ respondents with adolescent girls during cyclone Mahasen, $46.21 \%$ during cyclone Roanu and $62.12 \%$ during cyclone Mora did not take refuge to shelter. The number of refusal increases with time as a negative review about shelter condition comes from those who already have taken shelter.

Apart from the survey results, FGD and KII also exhibit some reason for not going to shelter: poor road network, unsafe condition of cyclone shelter for female, disbelief about warning, fatalism and superstitious religious belief.

\section{Is There any Change from Previous Study?}

Results of this study have similarities with previous observations, mainly the reasons including fear of burglary or theft, disbelief of the warning, fatalism, belief that their houses are strong enough, previous experience of the failure of warning, unsafe condition of cyclone shelter and superstitious religious belief (Haque and Blair, 1992; Chowdhury et al., 1993; Paul and Rahman, 2006; Paul, 2008; Paul and Routray, 2011). However, one of the main reasons for nonresponse is related to cyclone shelters issue should get more attention.

Although there are considerable numbers of buildings which are used as cyclone shelters, still many of these are damaged or in dilapidated condition. Therefore, people refused to take shelter in those buildings. Lack of maintenance of these shelters makes them unsafe. Moreover, improper distribution of shelters is a problem for the study area. An abandoned hospital and a school (Kalapania High School) are situated near the fishermen community of the study area. However, these buildings are not suitable for the person with disabilities (PWDs) and aged one. It is not possible to maintain female safety in those building. Photograph 1 shows a recently built college named Uttar Sandwip College. This college building has been constructed with facilities of a new cyclone shelter which is suitable for PWDs and old/aged people (photograph 1b.). However, this newly built shelter is far from the fishermen village. So for this vulnerable community, a shelter must be built or renovated (school building). Shelter for keeping domestic animals/birds is also necessary for the study area.
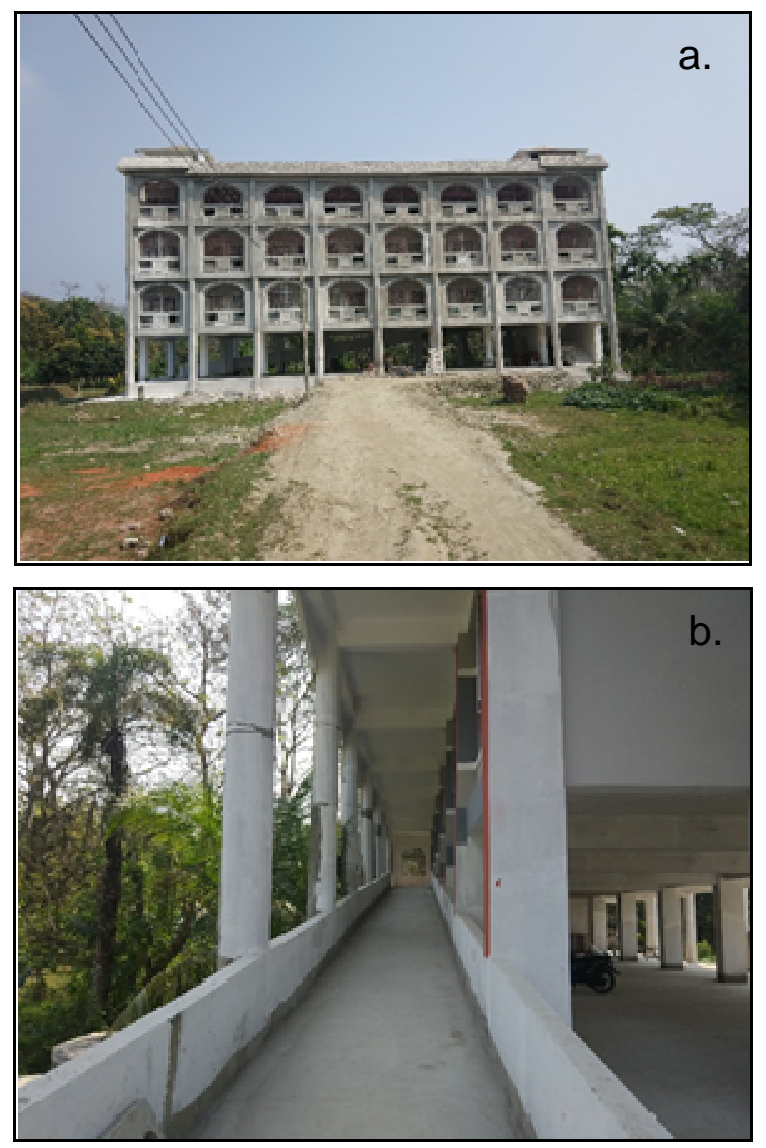

Photograph 1: The College to be Used as Cyclone Shelter: a. outside of the shelter b. ramp of the shelter.

Source: Field study, 2018

This study has revealed a lack of awareness or knowledge regarding cyclone hazards among the inhabitants. Sometimes delayed response to early warning occurs due to the closeness of cyclone shelters as they waited for the cyclone to hit and then evacuate. So the distance to cyclone shelter is a crucial determinant of response time to early warning.

However, there is positive change revealed in this study. It showed that female position in the family and attitude towards them did not prohibit them from going to shelter without the permission of the male members, as mentioned in previous research (Howell, 2003). Additionally, this study reveals that women and children got priority while going to a safer place or shelters. The male (head of the household) remains in the house and sends the female, infants and senior members to the shelters. Even so, the problem increases when families have adolescent girls and young women with the family. The securities on the way to shelters and at the shelters are not sufficient. Incidents of gender-based abuses, assaults, threats 
and violence have been revealed in previous research and also mentioned by the respondents in this research. These problems appear to have increased in the coastal regions, especially during disasters or in an emergency (Rezwana and Pain, 2017).

\section{Conclusion}

This study has been carried out to investigate the causes of reluctances of people to respond to the cyclone warning during three cyclones of the Bay of Bangle formed from 2013-2017 (M ohasen 2013, Roanu 2016 and M ora 2017). Inhabitants of the coastal area of Bangladesh are habituated with the risks and consequences of a cyclone as they face this hazard regularly. Regardless of this fact, many of them still refuse to take shelter during a cyclone. Though the number has increased during the last two decades, still there are a large number of people who remain in their house even after receiving the evacuation warning. The reasons for non-response include fear of theft, previous experience of the failure of warning, unsafe condition of cyclone shelters, superstitious religious belief, thinking that their houses are more durable than cyclone shelter and fatalism. This study found that distance of cyclone shelter determines evacuation time of inhabitants. People lives close to the shelters start evacuation at the eleventh hour.

In recent decades, Bangladesh becomes quite successful in cyclone early warning dissemination and reduces the number of human causalities. The result of this study also reflects this fact. Almost all of the respondents receive an early warning during the cyclone. Moreover, the number of cyclone shelters has been increased. This study finds out the reasons for peoples' non-response to cyclone warning despite these developments in Bangladesh.

The result of the study recommends improving the infrastructural facilities of the study area. $M$ aintenance of the infrastructures that are used as a cyclone shelter should be on top priority.

An abandoned hospital and a school (Kalapania high school) are situated very close to the fishermen communities which were once used as a cyclone shelter. However, these buildings are partially damaged and risky for use due to lack of maintenance. It is recommended that these two infrastructures should be renovated until a new one is constructed. These buildings will quickly gain the trust of the inhabitants due to the location. However, the roads of this village are in terrible conditions. These roads, especially connected to the shelters, should get high priority for renovations. The photograph shows (Photograph $1 \mathrm{a}$ and $1 \mathrm{~b}$ ) a new multipurpose building (cyclone shelter and college) has been constructed with all facilities for senior citizens, a person with disabilities (PWDs) and domestic animals. The connecting roads of the shelter should get proper attention too. Assuring safety at the evacuated houses will also help to increase the timely response rate. Local administration and volunteers can play these roles along with the warning dissemination.

Raising awareness among people about the severity of the hazard, the safety measures and better knowledge about the formation of the cyclone is needed. To eradicate the mistrust and disbelief regarding the early warning can be helpful. Awareness-raising activities would be more fruitful through educational institutions or educational schemes, including co-curricular activities. Awareness training program considering gender, age and socio-economic conditions would be more effective and successful. Especially training for women and senior citizens staying at home is needed for this area. Married women in this area are confined within the house for responsibilities and cultural expectations. It is recommended that awareness program should be arranged at the house yards to increase their access and attendance.

The resilience of the people should be increased through the integration of disaster risks reduction approach in planning, policy and development activities.

\section{References}

Akter, N. (2015). Are Cyclones Formed in the Bay Different? The Daily Star, March 08, Retrieved from https:// www.thedailystar.net/are-cyclones-formed-in-the-baydifferent-47798, Viewed on: January 25, 2018.

Alam, E. and Collins, A. E. (2010). Cyclone Disaster Vulnerability and Response Experiences in Coastal Bangladesh. Disasters 34(4): 931-954.

Banglapedia (2014). Sandip Upazila, Dhaka: Asiatic Society of Bangladesh, Retrieved from: http://en.banglape dia.org/index.php?title=Sandwip_Upazila, Viewed on: January 25, 2018.

Banglapedia (2014). Cylone, Dhaka: Asiatic Society of Bangladesh, Retrieved from: http://en.banglapedia.org /index.php?title=Cyclone, Viewed on: January 28, 2018.

BBS (2013). District Statistics 2011 Chittagong, Dhaka: Bangladesh Bureau of Statistics, Retrieved from: http://203.112.218.65:8008/WebTestApplication/userf 
iles/Image/ District\%20Statistics/Chittagong.pdf, Viewed on: January 27, 2018.

Charnkol, T. and Tanaboriboon, Y. (2006). Tsunami Evacuation Behavior Analysis- One Step of Transportation Disaster Response. IATSS Research, 30 (2): 83-96.

Chowdhury, A. M. R., Bhuyia, A. U., Choudhury, A. Y. and Sen, R. (1993). The Bangladesh Cyclone of 1991: Why So M any People Died. Disasters, 17 (4): 291-304.

Eisenman, D. P., Cordasco, K. M., Asch, S., Golden, J. F. and Glik, D. (2007). Disaster Planning and Risk Communication with Vulnerable Communities: Lessons from Hurricane Katrina, American Journal of Public Health. 97 (S1): 109-115.

Elder, K., Xirasagar, S., Miller, N., Bowen, S. A., Glover, S. and Piper, C. (2007). African Americans' Decisions Not to Evacuate New Orleans Before Hurricane Katrina: A Qualitative Study, American Journal Of Public Health, 97 (S1): 124-129.

Haque, C. E. and Blair, D. (1992). Vulnerability to Tropical Cyclones: Evidence from the April 1991 Cyclone in Coastal Bangladesh. Disasters, 16 (3): 217-229.

Haque, U., Hashizume, M.; Kolivras, K. N.; Overgaard, H. J., Das, B. and Yamamoto, T. (2012). Reduced Death Rates from Cyclones in Bangladesh: What More Needs to be done? Bulletin of the World Health Organization 2012 (90): 150-156.

Howell, P. (2003). Indigenous Early Warning Indicators of Cyclones: Potential Application in Coastal Bangladesh. Benfield Hazard Research Centre, Retrieved from: https://www.preventionweb.net/files/1529_workingpa per6.pdf, Viewed on: January 25, 2018.

Islam, M. S., Ullah, M. S. and Paul, A. (2004). Community Response to Broadcast M edia for Cyclone Warning and Disaster Mitigation: A Perception Study of Coastal People with Special Reference to Meghan Estuary in Bangladesh, Asian Journal of Water, Environment and Pollution, 1 ( $1 \& 2)$ : 55-64.

Lazo, J. K., Waldman, D. M., Morrow, B. H., and Thacher, J. A. (2010). Household Evacuation Decision Making and the Benefits of Improved Hurricane Forecasting: Developing a Framework for Assessment, Weather and Forecasting, 25 (1): 207-219.

Paul A. and Rahman, M. M. (2006). Cyclone Mitigation Perspectives in the Islands of Bangladesh: A Case of Sandwip and Hatia Islands, Coastal Management, 34 (2): 199-215.

Paul B. K. (2008). Hazard Warnings and Compliance with Evacuation Orders: The Case of Bangladesh's Cyclone Sidr, Colorado: The Natural Hazards Center, University of Colorado at Boulder, Quick Response Report.
Paul, B. K. (2010). Human Injuries Caused by Bangladesh's Cyclone Sidr: An Empirical Study. Natural Hazards, 54 (2): 483-495.

Paul, B. K. and Dutt, S. (2010). Hazard Warnings and Responses to Evacuation Orders: The Case of Bangladesh's Cyclone Sidr. Geographical Review, 100 (3): 336-55.

Paul, S. K. and Routray J. K. (2013). An Analysis of the Causes of Non-responses to Cyclone Warnings and the Use of Indigenous Knowledge for Cyclone Forecasting in Bangladesh, in Filho W. L. (Ed.) Climate Change and Disaster Risk Management. Springer, Berlin, Heidelberg, 15-39.

Paul, S. K. (2014). Determinants of Evacuation Response to Cyclone Warning in Coastal Areas of Bangladesh: A Comparative Study, Oriental Geographer 55 (1 \& 2): 5784.

Paul, S. K. and Routray, J. K. (2011). Household Response to Cyclone and Induced Surge in Coastal Bangladesh: Coping Strategies and Explanatory Variables. Natural Hazards, 57 (2): 477-499.

Reininger, B. M., Raja, S. A., Carrasco, A. S., Chen, Z., Adams, B., M cCormick, J. and Rahbar, M. H. (2013). Intention to Comply with Mandatory Hurricane Evacuation Orders Among Persons Living Along a Coastal Area, Disaster M edicine and Public Health Preparedness, 7(1): 46-54.

Rezwana, N. (2018). Refusing Safe Shelter during Cyclone Warning: A Case Study of Cyclone Roanu in Bangladesh, in Khatun, H., Ahmad, N., M ahbub A. Q. M. and Kabir M. H. (Eds.). Environment and Sustainable Development in Bangladesh, Geographical Perspectives, Dhaka: Department of Geography and Environment, University of Dhaka.

Rezwana, N. and Pain, R. (2017). Understanding GenderBased Violence during Disasters in the Coastal Region of Bangladesh, Newcastle upon Tyne: Newcastle University, Retrieved from: https://eprint.ncl.ac.uk/24 5488, Viewed on January 25, 2018.

Smith, S. K. and M cCarty, C. (2009). Fleeing the Storm(s): an Examination of Evacuation Behavior during Florida's 2004 Hurricane Season, Demography, 46 (1): 127-145.

Uddin, M. M. and Ciavola, P. (2012). Geomorphological Evaluation and Coastal Changes of Sandwip Island, Eastern GBM Delta, Bangladesh, Conference Proceedings: Italy-Cina: An Ancient Cultural Heritage and the Challenge for Future Development, Bologna, Italy, October 22 - 23, 2012, 181-188.

Whitehead, J. C., Edwards, B., Willigen, M. V., Maiolo, J. R., Wilson, K., and Smith, K. T. (2000). Heading for Higher Ground: Factors Affecting Real and Hypothetical Hurricane Evacuation Behavior. Global Environmental Change Part B: Environmental Hazards, 2 (4): 133-142. 